\title{
Biochemical aspects of inorganic nitrogen assimilation by woody plants
}

\author{
G.R. Stewart, J. Pearson, J.L. Kershaw and E.C.M. Clough
}

Department of Biology (Darwin Building), University College London, Gower Street, London WC1E 6BT, U.K.

\section{Introduction}

For the majority of woody plants, the mineralization of organic nitrogen in soil provides their source of nitrogen for growth. The relative activities of ammonifiers and nitrifiers, as influenced by a complex interaction of abiotic and biotic factors, will determine the availability of ammonium and nitrate ions, both spatially and temporarily. Nitrification rates show considerable variation in different forest soils and, for the most part, this is unrelated to total nitrogen, $\mathrm{pH}$ or carbon:nitrogen ratio (Robertson, 1982).

Not surprisingly, woody plant species exhibit differences in their capacities to utilize nitrate and ammonium ions (see e.g., Chandler, 1981). These differences relate in part at least to the prevalent form of available nitrogen in their ecological niche. However, the assimilation of ammonium and nitrate ions carries different potential costs with respect to energy and water requirements, with ammonium ions being the more cost-effective nitrogen source (Raven, 1985). Differences in cost effectiveness of nitrate and ammonium ions may be important with respect to the growth of understorey trees and shrubs in light- and water-limited environments, particularly as these species have high maintenance costs.

In this report, we will consider the characteristics of inorganic nitrogen assimilation in woody plants. The occurrence and localization of nitrate reductase and glutamine synthetase isoforms will be discussed.

\section{Nitrate reduction}

Nitrate assimilation in higher plants is catalyzed by 2 enzymes: pyridine nucleotide-linked nitrate reductase and ferredoxin-linked nitrite reductase. The capacity for nitrate reduction is widespread among woody plants (see, e.g., Smirnoff et al., 1984; Stewart et al., 1988), although certain taxonomic groups exhibit a low capacity for leaf nitrate reduction. Rates of nitrate reduction in many gymnosperms and members of the Proteaceae and Ericaceae are at the low end of the range reported for higher plants (Smirnoff 
et al., 1984). In a recent study of Australian rain forest plants, many understorey trees and shrubs were found to utilize nitrogen sources other than nitrate and to have a low capacity for nitrate reduction (Stewart et al., 1988).

Leaf nitrate reductase is a cytosolic enzyme which utilizes NADH as reductant. Trees of the genus Erythrina are quite atypical in having a nitrate reductase which can utilize both NADH and NADPH (Orebamjo et al., 1982). However, this enzyme has a high $K_{\mathrm{m}}$ for nitrate $(10 \mathrm{mM})$, this being $20-100$ times greater than $K_{\mathrm{m}}$ values reported for $\mathrm{NADH}$ nitrate reductases (Orebamjo et al., 1982). The activity of nitrate reductase in Erythrina species is very high, $20-50$ pkat.g fw-1. There are no other reports of woody plants having this unusual form of nitrate reductase and the physiological significance of a low affinity-high activity nitrate-reducing system is obscure. Although the properties of NADH-nitrate reductases are rather uniform, there are considerable differences between species as regards the sites of nitrate reduction. Measurements of the distribution of nitrate reductase activity between roots and shoots and of xylem sap nitrogenous compounds have led to the recognition of 3 groups of plants. One group consists of species in which the shoot is the major site of nitrate reduction and in these species little reduction occurs in their roots; a second group comprises species which exhibit the capacity for both root and shoot nitrate reduction and in which nitrate ions as well as reduced forms of nitrogen are present in the xylem sap; the third group includes species in which the root is the major site of nitrate reduction and little or no nitrate is present in xylem sap (see Pate, 1983). Andrews (1986) suggests that 3 generalizations can be made with respect to the partitioning of nitrate assimilation between roots and shoots: 1) temperate perennial species assimilate nitrate in their roots when the external concentration of nitrate is low $<1$ $\mathrm{mol} \cdot \mathrm{m}^{-3}$ and, as this is increased, shoot nitrate reduction becomes more important; 2) temperate annual species carry out most of their nitrate reduction in the shoot, irrespective of external nitrate reduction;

Table I. Root-shoot partitioning of nitrate reductase in woody plants.

\begin{tabular}{lll}
\hline $\begin{array}{l}\text { Shoot-root NRA } \\
<1.0\end{array}$ & Shoot-root NRA & Shoot-root NRA \\
$1-5$ & $>5.0$ \\
\hline Aegiceras corniculatum & Aspidospermum australe & Astronium lecointeri \\
Aegialitis annulata & Anadenanthera pergrina & Cedrella fissilis \\
Avicennia nitida & Casearia sylvestris & Chorisia speciosa \\
Bauhinia rufescens & Cordia eucalypta & Croton urucurana \\
Calophyllum brasiliense & Dalbergia brasiliense & Ficus exasperata \\
Centrolobium tomentosum & Enterolobium contortisilicum & Genipa americana \\
Dimorphandra mollis & Hymenea coubaril & Guierra senegalensis \\
Kielmeyera coriacea & Lonchocarpus muellbergiana & Hybanthus atropurpurea \\
Pithecellobium dulce & Machaerium stipitatum & Nectramdra rigida \\
Rhizophora mangle & Metrodonea nigra & Solanum prianthum \\
Styrax sp. & Platypodium elegans & Urera barrifra \\
& Prunus sellowii & Tabebuia chrysotricha \\
& Pterocarpus violacea & \\
& Rapanea ferruginea & \\
& Rauvolfia vomitoria & \\
& Schinus terebentifolium & \\
\hline
\end{tabular}

See Stewart et al. (1988) for assay details. 
3) tropical and subtropical species both annual and perennial carry out nitrate assimilation predominantly in their shoots, external nitrate concentration having little effect on the localization of assimilation. However, studies of the distribution of nitrate reductase activity (NRA) between the roots and shoots of tropical and subtropical trees indicate that about $30 \%$ of the species exhibit shoot to root nitrate reductase ratios of less than 1 , for $40 \%$ of the species, the ratio was between 1 and 5 and, for the remaining $30 \%$, the ratio was greater than 5 (see Table I).

Moreover, most of the species examined showed marked changes in shoot to root nitrate reduction when the nitrate supply was increased. Typically, species with high shoot nitrate reductase activities are those characteristic of forest margins and gaps and early stages of forest succession. Previous studies of herbaceous and woody species (Stewart et al., 1987) and Australian rain forest species (Stewart et al., 1988) also support this idea that shoot nitrate reduction is a characteristic of pioneer species both temperate and tropical.

Many of the woody species, which in pot experiments exhibit a predominance of root nitrate reduction, are species which can either utilize dinitrogen through symbiotic association with a prokaryotic nitro- gen fixer or are species which normally grow in habitats where ammonium ions are likely to be the available nitrogen source. The assimilation of ammonium ions derived from dinitrogen or directly absorbed from the soil solution occurs exclusively in the root system. Consequently, these species have the necessary biochemical components for nitrogen assimilation in their root cells, are active in the transport of nitrogenous compounds between root and shoot and their leaves are biochemically competent in the catabolism and re-assimilation of translocated nitrogenous compounds. A predisposition to root nitrate reduction may simply be a consequence of an obligatory root nitrogen assimilation imposed by adaptation to dinitrogen or ammonium ion utilization.

\section{Pathways of ammonium ion assimila- tion}

Various approaches, including $15 \mathrm{~N}$-tracer studies, the use of enzyme-specific inhibitors and studiess with mutants lacking one or more of the assimilatory enzymes, give results consistent with the view that ammonium assimilation occurs through the combined action of glutamine synthetase

Table II. Ammonium assimilating enzymes in the roots and shoots of woody plants.

\begin{tabular}{|c|c|c|c|c|c|c|}
\hline \multirow[t]{3}{*}{ Species } & \multicolumn{6}{|c|}{ Enzyme activity (nkat'g fw-1) } \\
\hline & \multicolumn{3}{|l|}{ root } & \multicolumn{3}{|c|}{ shoot } \\
\hline & $\overline{G S}$ & GOGAT & $G D H$ & GS & GOGAT & $G D H$ \\
\hline Avicennia nitida & 150 & 60 & 758 & 200 & 312 & 207 \\
\hline Dalbergia ecastophyllum & 200 & 70 & 400 & 515 & 300 & 295 \\
\hline Kielmeyera coriacea & 189 & 16 & 280 & 291 & 256 & 558 \\
\hline Peltophorum dubium & 116 & 6 & 107 & 381 & 122 & 907 \\
\hline Pseudobombax marginatum & 130 & 48 & 1014 & 391 & 160 & 545 \\
\hline Trema guineensis & 100 & 20 & 800 & 450 & 310 & 287 \\
\hline
\end{tabular}

See Stewart et al. (1988) for assay details. 
and glutamate synthase and that glutamate dehydrogenase (GDH) makes, at the best, a minor contribution (see Wallsgrove, 1987). There have been few studies of the ammonia assimilatory enzymes in woody plants. Glutamine synthetase has been demonstrated in leaves of several tree species (Chandler, 1981; NcNally et al.,1983; Stewart et al., 1988).

The results in Table II show the presence of glutamine synthetase (GS) and glutamate synthase (GOGAT) in shoots and roots of woody plants representative of a range of forest types. In common with many herbaceous species, substantial activities of glutamate dehydrogenase are present, particularly in roots. Avicennia nitida roots exhibit high activities of NADH glutamate dehydrogenase which are nearly 5 times greater than those of glutamine synthetase. However, when such roots are treated with methionine sulphoximine, an inhibitor of glutamine synthetase, not only is glutamine synthesis inhibited but there is also an accumulation of ammonium ions and a decline in the concentrations of amino acids. These results suggest that, even in tissues where the activity of glutamate dehydrogenase is high, the preferred pathway of ammonium assimilation is the glutamate synthase cycle.

A combination of ${ }^{15} \mathrm{~N}$-labelling and enzymic specific inhibitors has been used to determine the pathway of ammonium assimilation in isolated beech mycorrhizal roots and the results again suggest the operation of the glutamate synthase cycle (Martin et al., 1986). Glutamate dehydrogenase was found to play little if any part in mycorrhizal ammonium assimilation, even though studies of the mycorrhizal fungus suggest it assimilates ammonium by the glutamate dehydrogenase route (Genetet et al., 1984). However, our recent studies with another mycorrhizal fungus, Pisolithus tinctorius, suggest it may utilize the glutamate synthase cycle rather than glutamate dehydrogenase for ammonium assimilation.

\section{Glutamine synthetase isoforms}

Although the first enzyme of the glutamate synthase cycle is ubiquitous in plant tissues, it occurs as tissue/organ-specific isoforms, whose activities differ between species. There is a root-specific isoform and in legumes there is a nodule isoform (Cullimore et al., 1983). The leaves of many species have 2 isoforms, one located in the chloroplasts and the other in the cytosol (Mann et al., 1979; McNally et al., 1983).

Among woody plants, there are considerable differences in the relative proportions of chloroplastic and cytosolic isoforms (see (McNally et al., 1983; Stewart et al., 1987). Recently, it has been shown that the leaves of woody pioneer species exhibit predominantly the chloroplastic isoform, while, in the leaves of species typical of closed, climax forest, the cytosolic isoform predominates (Stewart et al., 1988). Moreover, several of these trees of climax forest appear to lack the chloroplastic isoform (Stewart et al., 1987; 1988). Other higher plants in which the chloroplastic isoform is absent are achlorophyllous parasitic species (McNally et al., 1983). Woody species which exhibit low levels or completely lack chloroplastic glutamine synthetase also have a low capacity for leaf nitrate reduction (Stewart et al., 1988). Low levels of chloroplastic glutamine synthetase imply re-assimilation of photorespiratory ammonium by cytosolic glutamine synthetase. Curiously, the original model for the photorespiratory nitrogen cycle did, in fact, propose that the ammonium released was re-assimilated by cytosolic glutamine synthetase (Keys et al., 1978). However, the absence of this 
isoform in many $\mathrm{C}_{3}$ species (McNally et al., 1983) and the rapid accumulation of ammonium under photorespiratory conditions in mutants lacking chloroplastic glutamine synthetase (Wallsgrove, 1987) led to an acceptance of the idea that photorespiratory ammonium is re-assimilated by the chloroplastic isoform. Our observations with woody plants suggest species differ in the extent to which cytosolic and chloroplastic isoforms participate in the photorespiratory nitrogen cycle and that no simple generalization can be made.

\section{Conclusions}

The results presented here indicate that inorganic nitrogen assimilation in woody plants resembles, in general, that of herbaceous species. The differences observed between species relate to the site(s) of nitrate assimilation at the whole plant level and the site of glutamine synthesis at the cellular level.

Woody pioneer species exhibit a high capacity for nitrate reduction and are in general leaf assimilators of nitrate. In most, chloroplastic glutamine synthetase accounts for most of the total leaf activity. In contrast, many under- and overstoreyspecies generally utilize sources of nitrogen other than nitrate but, if nitrate ions are available, they are assimilated in the root system. Many tree species with a low capacity for leaf nitrate reduction exhibit low levels of chloroplastic glutamine synthetase and assimilate photorespiratory ammonium in the cytosol of leaf cells.

These differences in sites of nitrate and ammonium ion assimilation at the whole plant and cellular levels may relate to the influence of light on nitrogen metabolism. In leaf cells, the reductant and ATP for nitrate reduction and the subsequent as- similation of ammonium can be generated directly by the light reactions of photosynthesis. If photosynthesis is light-saturated, as is likely for pioneer species, then there will be sufficient reductant and ATP to support these reactions and those of $\mathrm{CO}_{2}$ assimilation. If, however, light is limiting, as will be the case for understorey plants and for overstorey species early in their growth, nitrate and ammonium ions will compete with $\mathrm{CO}_{2}$ for photochemical energy. Thus the spatial separation of both nitrate reduction, in the roots, and ammonium re-assimilation, in the cytosol, from $\mathrm{CO}_{2}$ assimilation in the chloroplast provides a mechanism which allows control over the use of limited light between the assimilatory reactions of carbon and nitrogen metabolisms.

\section{Acknowledgments}

Financial support from the Science and Engineering Research Council (GR/D/75618) and the Natural Environmental Research Council (GST02344) is gratefully acknowledged.

\section{References}

Andrews M. (1986) The partitioning of nitrate assimilation between root and shoot of higher plants. Plant Cell Environ. 9, 511-519

Chandler G. (1981) Physiological aspects of rainforest regeneration $\mathrm{l}$. Effects of light and nitrogen source on growth and ammonium assimilating enzymes of Solanum mauritanum and Syzygium floribundum. New Phytol. 87, $301-313$

Cullimore J.V., L.ara M., Lea P.J. \& Miflin B.J. (1983) Purification and properties of two forms of glutamine synthetase from the plant fraction of Phaseolus root nodules. Planta 157, 245-253

Genetet I., Martin F. \& Stewart G.R. (1984) Nitrogen assimilation in mycorrhizas. Ammonia assimilation in the $\mathrm{N}$-starved ectomycorrhizal 
fungus Cenococcum graniforme. Plant Physiol. 76, 395-399

Keys A.J., Bird I.F., Cornelius M.F., Lea P.J., Wallsgrove R.M. \& Miflin B. (1978) Photorespiratory nitrogen cycle. Nature 275, 741-742

Mann A.F., Fentem P.A. \& Stewart G.R. (1979) Identification of two forms of glutamine synthetase isoforms in barley (Hordeum vulgare). Biochem. Biophys. Res. Commun. 88, 515-521

Martin F., Stewart G.R., Genetet I. \& Le Tacon F. (1986) Assimilation of $15 \mathrm{NH}_{4}$ by beech (Fagus sylvatica L.) ectomycorrhizas. New Phytol. 102, 85-94

McNally S.F., Hirel B., Gadal P., Mann A.F. \& Stewart G.R. (1983) Glutamine synthetases of higher plants. Evidence for a specific isoform content related to their possible physiological role and their compartmentation within the leaf. Plant Physiol. 72, 22-25

Orebamjo T.O., Porteus G. \& Stewart G.R. (1982) Nitrate reduction in the genus Erythrina allertonia. $3,11-18$

Pate J.S. (1983) Patterns of nitrogen metabolism in higher plants and their ecological significance. In: Nitrogen as an Ecological Factor. (Lee J.A., McNeil S. \& Rorison 1.H., eds.), Blackwell, Oxford, pp. 225-256
Raven J.A. (1985) Regulation of $\mathrm{pH}$ and osmolarity generation in vascular land plants: costs and benefits in relation to the efficiency of use of water, energy and nitrogen. New Phytol. 101, 25-77

Robertson G.P. (1982) Nitrification in forested ecosystems. Philos. Trans. $R$. Soc. London B. 296, 445-457

Smirnoff N., Todd P. \& Stewart G.R. (1984) The occurrence of nitrate reduction in the leaves of woody plants Ann. Bot. 54, 363-374

Stewart G.R., Hegarty E.E. \& Specht R.L. (1988) Inorganic nitrogen assimilation in plants of Australian rainforest communities. Physiol. Plant. 74, 26-33

Stewart G.R., Sumar N. \& Patel M. (1987) Comparative aspects of inorganic nitrogen assimilation in higher plants. In: Inorganic Nitrogen Metabolism. (Ullrich W.R., Aparicio P.J., Syrett P.J. \& Costilla F.C., eds.), Springer-Verlag, Berlin, pp. 39-44

Wallsgrove F.M. (1987) The role of glutamine synthetase and glutamate synthase in nitrogen metabolism of higher plants. In: Organic Nitrogen Metabolism. (Ullrich W.R., Aparicio P.J., Syrett P.J. \& Costilla F., eds.), Springer-Verlag, Berlin, pp. 137-141 